\title{
Prevalence of Red Cell Alloantibodies in Pregnant Women
}

Sahoo BB ${ }^{1}$, Mahapatra $\mathrm{S}^{1 *}$, Mishra $\mathrm{S}^{2}$, Mishra $\mathrm{D}^{3}$, Panigrahy $\mathrm{R}^{4}$ and Parida $\mathrm{P}^{1}$

${ }^{1}$ Department of Transfusion Medicine, S.C.B. Medical College, India

${ }^{2}$ Department of Pathology, S.C.B. Medical College, India

${ }^{3}$ Department of Transfusion Medicine, AIIMS, India

${ }^{4}$ Department of Transfusion Medicine, M.K.C.G. Medical College, India

\section{Research Article}

Volume 4 Issue 1

Received Date: January 27, 2020

Published Date: February 12, 2020

DOI: $10.23880 /$ hij-16000154

*Corresponding author: Smita Mahapatra, Associate Professor, Department of Transfusion Medicine, SCB Medical College \& Hospital, Cuttack, Odisha, India, Tel: 91-9437094138; Email: doctorsmita@rediffmail.com, dr.smitamahapatra@gmail.com

\section{Abstract}

Background: Red cell alloimmunization results genetic disparity of Red Blood Cell (RBC) antigen between the fetus and mother in pregnancy. The development in red cell alloimmunization in pregnancy occurs as a consequence of transplacental movement of fetal RBC either during delivery, miscarriage, ectopic pregnancy or during invasive procedure like amniocentesis. Alloimmunization is significant especially when it involves a clinically significant alloantibody that causes hemolytic transfusion reaction and fetal anemia leading to hemolytic disease of fetus and newborn (HDFN).

Aim: To identify and estimate the frequency of red cell alloimmunization among Rh-D negative and Rh-D positive pregnant women as well as establishing a screening protocol and management protocol to reduce the rate of haemolytic diseases of fetus and newborn.

Material and methods: This is a prospective study of antenatal mothers for a period of one year and nine months conducted in Transfusion Medicine Department of SCB Medical College \& Hospital, Cuttack. A total of 362 pregnant mothers irrespective of their gestational period and meeting the eligibility criteria and giving consent were included in our study. Blood grouping and Rh-typing, Antibody screening, Antibody Identification were done by Conventional Test Tube (CTT) method, 3-cell panel and 11-cell panel respectively. Titer of the identifying antibodies was done by serial, two fold double dilution method using CTT.

Results: Out of 362 pregnant women, 13(3.6\%) women showed positive antibody screening. A total number of 14 antibodies were identified. The Red cell allo-immunization among Rh-D negative women and Rh-D positive women were $4.42 \%$ and $2.2 \%$ respectively. The antibodies identified were anti-D, anti-c, anti-E, anti-C and anti-Le ${ }^{\mathrm{a}}$. Both single and multiple antibodies were detected in our study. We found $0.59 \%$ primigravida showing positive antibody screening. The antibody titer in two cases was above the critical level.

Conclusion: The alloimmunization was found not only in Rh-D negative but also in Rh-D positive pregnant women. So universal antenatal screening in pregnant mothers should be initiated. The titer of the antibody should be closely monitor and 
Abbreviations: RBC: Red Blood Cell; HDFN: Hemolytic Disease of Fetus and Newborn; CTT: Conventional Test Tube; OPD: Outpatient Department; EDTA: Ethylene Diamine Tetraacitic Acid; SOP: Standard Operating Procedure.

\section{Introduction}

Blood group antibodies are immunoglobulins that react with corresponding antigens on the surface of red blood cells. They can either be acquired naturally or through immunization in response to antigen present on red cells which is foreign for the individuals [1]. The naturally occurring antibodies are produced in response to the stimulants such as bacteria in the diet and gastrointestinal microbes [2]. Karl Landsteiner first described the ABO blood group system in 1900 [3]. A total of 347 RBC antigens have been recognized by international society of blood transfusion till date, out of which 308 antigens are clustered in 36 blood group systems [4].

Red cell alloimmunization results from genetic disparity of RBC antigen between donor and recipient in multi transfused patients as well as in women due to pregnancy. The development of red cell alloimmunization in pregnancy occurs as a consequence of transplacental movement of fetal RBC either during delivery, miscarriage, ectopic pregnancy or during invasive procedure like amniocentesis [5].

Red blood cells have many surface antigens, out of which atleast 43 are being capable of producing hemolytic disease of fetus and newborn [6]. The antigens that are frequently associated with perinatal hemolytic diseases are $\mathrm{Rh}(\mathrm{D}, \mathrm{C}, \mathrm{E}$, c, e, f, C ${ }^{\mathrm{w}}$ );Kell(K, k-Cellano, $\mathrm{Kp}^{\mathrm{a}}, \mathrm{Kp}^{\mathrm{b}}$, Js $\mathrm{s}^{\mathrm{a}}$, Js ${ }^{\mathrm{b}}$ ); MNS(M, N, s, S);Kidd $\left(\mathrm{Jk}^{\mathrm{a}}\right.$, Jk $\left.{ }^{\mathrm{b}}\right)$;Duffy $\left(\mathrm{Fy}^{\mathrm{a}}, \mathrm{Fy}^{\mathrm{b}}\right)$ and Lutheran [7].

There was adequate available data regarding the prevalence of red cell alloimmunization and clinical significance of both $\mathrm{Rh}$ Positive and $\mathrm{Rh}$ negative antenatal mothers worldwide as well from Northern and Southern part of India. This study has been conducted for the first time in Eastern region of India.

The aim of our study was to screen and identify the red cell allo-antibodies both in Rh-D negative and Rh-D positive mothers within the state of Odisha to establish a better mother and child care during and after pregnancy. The objectives of our study stated as below. a) To identify and estimate the frequency of the red cell allo-antibodies both in Rh-D negative and Rh-D positive mothers.

b) To prevent complication of transfusion reaction due to incompatible blood transfusion in mother and child.

c) To establish a better screening protocol and management guideline to reduce the rate of haemolytic disease of fetus and newborn (HDFN).

d) To create awareness about the red cell allo-immunization among clinicians and general population.

e) To reduce the perinatal and neonatal mortality rate.

\section{Material and Methods}

The selected area for the study was the Department of Transfusion Medicine, Sriram Chanda Bhanja (SCB) Medical College \& Hospital which is located at the centre of Cuttack city in the state of Odisha .This is a prospective study on antenatal mother attending the outpatient Department (OPD) of Obstetrics \& Gynaecology, SCB Medical College \&Hospital, Cuttack between January 2015 to October 2016. The study was conducted on 362 pregnant women irrespective of their period of gestation and obstetrics history. Both Primigravida (G1) and multigravida Pregnant mothers in the age group of 18-40 years were selected for the study purpose. The study included both Rh-D positive and Rh-D negative pregnant mother for screening and identification of allo-antibodies. The medical history of each patient such as patient's name, age, obstetrics history, blood group, husband's blood group and history of blood transfusion were recorded prior to collection of the blood samples. The antenatal mothers meeting the eligibility criteria and giving consent were included in our study.

\section{Eligibility Criteria}

- Antenatal mother who are legally Adults (Age $\geq 18 y e a r s)$

- The pregnancy of the women confirmed by an obstetrician.

- Giving consent for the enrollment in the study

- Both Primigravida and multigravida irrespective of gestation.

\section{Exclusion Criteria}

The following antenatal women were excluded from the study population.

- Women who were not pregnant and pregnancy not confirmed by a obstetrician

- Antenatal mothers less than 18 years of age. 
- Pregnant women who had history of recent or previous transfusion.

- Rh-D negative mother who had received anti-D prophylaxis in the current and previous pregnancy.

- $\quad$ Pregnant but not giving consent.

Five millilitres of venous blood samples were collected in each plain and ethylene diamine tetraacitic acid (EDTA) vacuitainer vials. The EDTA vials were used to prepare cell suspension for blood grouping and Rh typing. The plain vacuitainer vials were allowed to clot and centrifuge at 3000rpm for 3 minutes to separate the serum from red cells. The serum samples of the antenatal mothers were used for antibody screening and identification. Samples that were not tested on the same day were stored at $2-8^{\circ} \mathrm{C}$ till next day.

ABO grouping (Forward and Reverse) and Rh-D typing were done on each patient's sample by using Conventional Test Tube (CTT) technique as per the Standard operating procedure (SOP) of our institution. Weak D phenotype was done for all donors typed D-negative as per manufactures instruction. The Bombay group was ruled out by using anti-H lectin.

It is recommended that routine red cell antibody screening in pregnant women to be done at the first visit and if no antibodies are detected, it is to be repeated in the third trimester between 28 and 36 weeks. Antibody screening was done with commercially available three panel cell (Reagent Red cell, Surgiscreen, OrthoClinic Diagnostic, USA) and coomb's glass bead cassette (Ortho Bio view, USA). The screened positive serum samples were used for identification of specific antibodies. A commercially available eleven cell panel (Ortho Bio view, USA) was used for antibody identification. The titres of the identified antibodies were done by double dilution method using CTT.

\section{Results}

A total number of 362 pregnant women were selected for the study purpose after fulfilling the eligibility criteria. Out of these, 136(37.57\%) were Rh-D positive and 226 (63.43\%) were Rh-D negative. Among Rh-D positive samples the group A individuals were 22(16.18\%), group-B 39(28.67\%), group- AB 9 (6.62\%) and that of group-O were $66(48.52 \%)$ and $\mathrm{Rh}-\mathrm{D}$ negative samples of group-A, group-B, group-AB and group-0 were $34(15.04 \%), 79$ (34.96\%), 5(2.21\%) and $108(47.79 \%)$ respectively (Figure 1$)$. The maternal age ranged from 18-40 yrs with a mean age of 26 years (25.55). The study population constituted 327(90. 33\%) case who were less than 30 years of age and 35(9.67\%) were equal to or more than 30 years of age (Figure 2) Out of 362 pregnant women, the primigravida (G1) women were $168(46.41 \%)$ and the multigravida were $194(53.59 \%)$ who were in the range from G2-G7 except G6. (Figure 3).

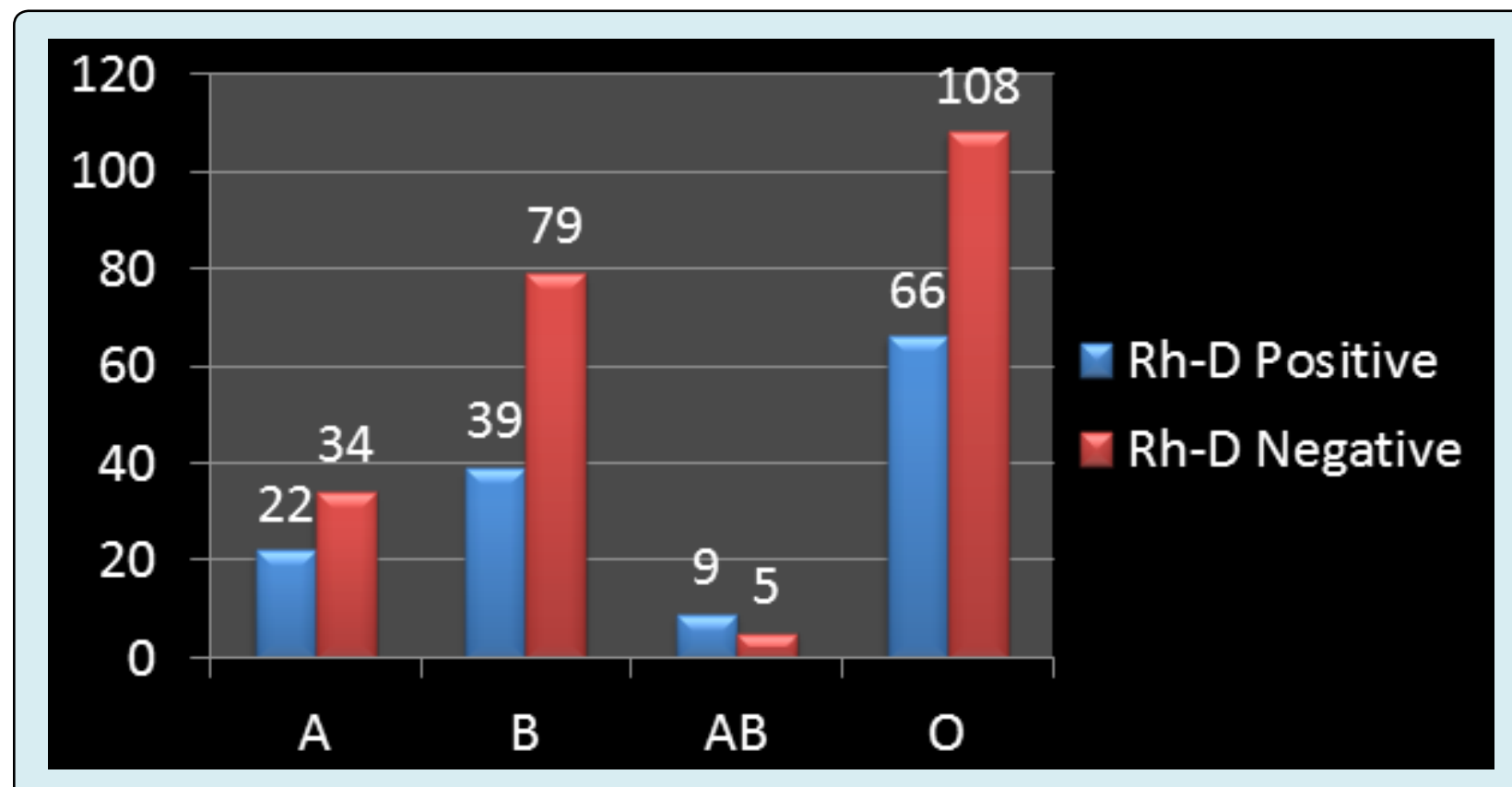

Figure 1: Distribution of ABO Status among Rh-D positive and Rh-D negative pregnant mothers. 


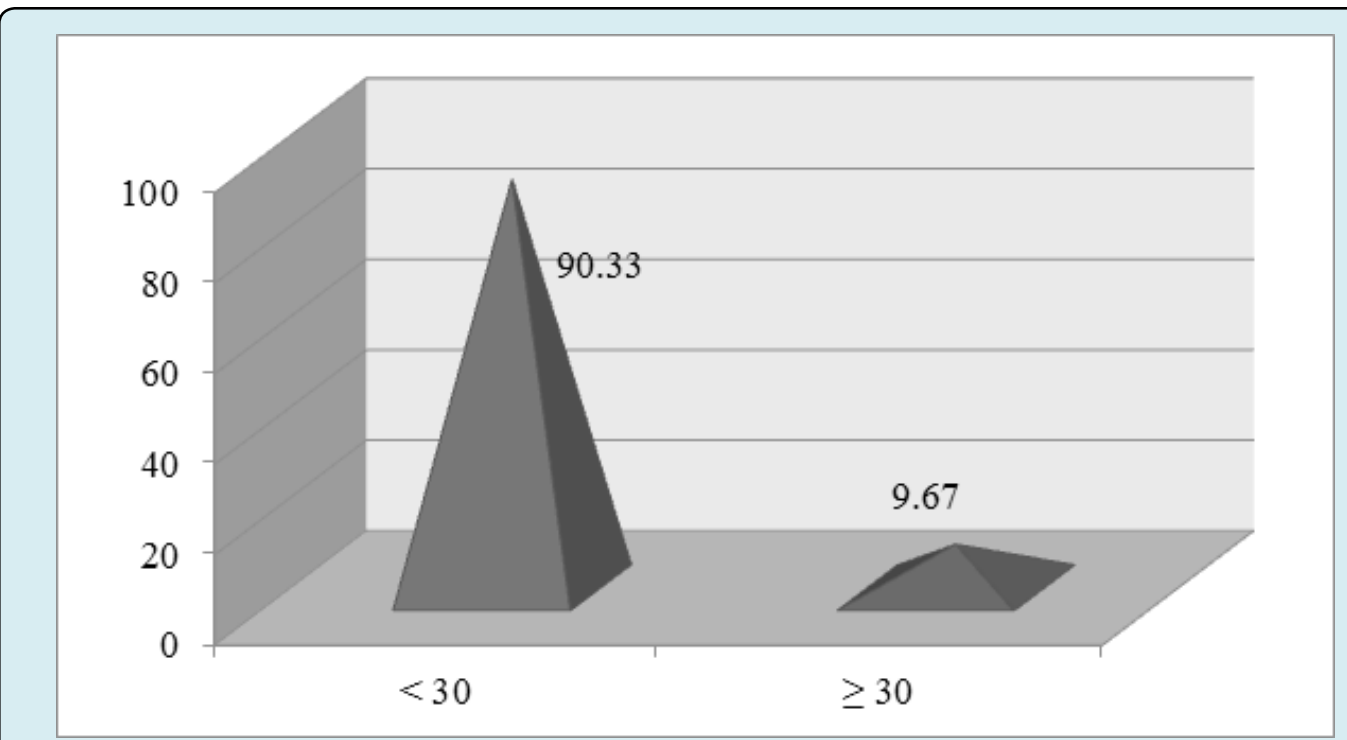

Figure 2: Distribution of Age in Pregnant women $(n=362)$.

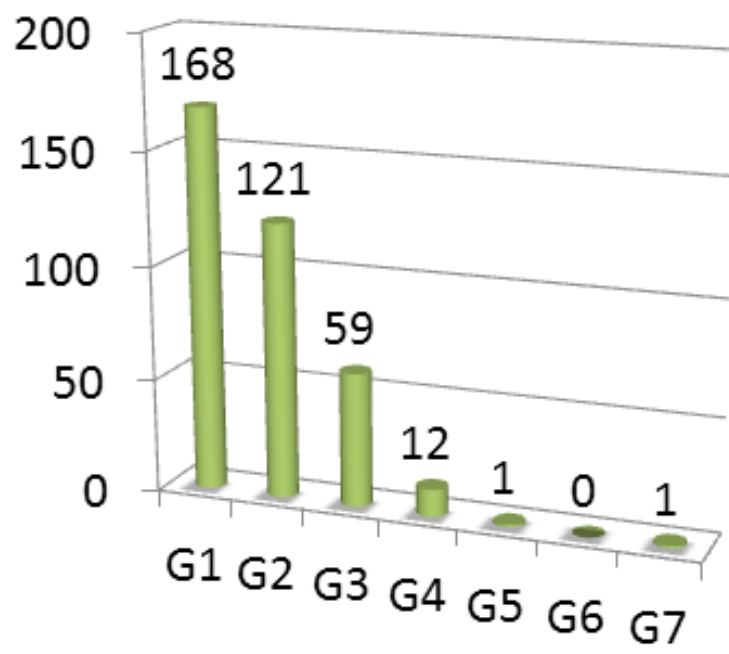

Number of pregnant women

Figure 3: Distribution of Subject in relation to Gravida status.

Out of 362 women screened for red cell allo-antibodies, 13 women showed positive screening. The total number of antibodies identified was 14 . The prevalence of red cell alloimmunization was $3.6 \%(13 / 362)$. The specificity of alloantibodies detected in study population is shown in Table 1. Both single and multiple alloantibodies were identified. Among alloantibodies sensitized women, Anti-D (53.85\%) was the most common alloantibody (Figure 4). Anti- D antibody was detected both single as well as combined with anti-C.

\begin{tabular}{|c|c|c|}
\hline Antibody detected & Number & Percentage \\
\hline Anti-D & 7 & 1.93 \\
\hline Anti-c & 2 & 0.55 \\
\hline Anti-E & 1 & 0.28 \\
\hline Anti-D + Anti-C & 1 & 0.28 \\
\hline Anti-Le $^{\mathrm{a}}$ & 2 & 0.55 \\
\hline Negative & 349 & 96.41 \\
\hline
\end{tabular}

Table 1: Specificity of the antibody detected in the study population $(n=362)$. 


\section{Haematology International Journal}

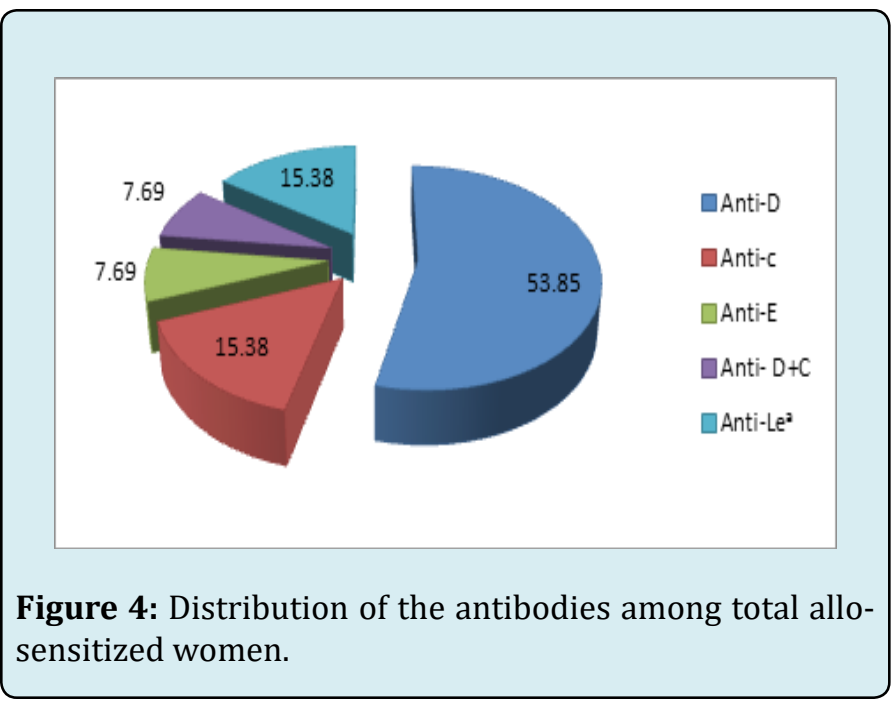

The study included both Rh-D negative and Rh-D positive women. The frequency of alloantibodies identified among Rh-D negative and Rh-D positive were $4.42 \%$ and $2.2 \%$ respectively. The antibody identified among Rh-D negative women were anti-D, anti-c, anti-D+anti-C and anti-Le ${ }^{\mathrm{a}}$ where as in Rh-D positive women identified antibodies were anti-E, anti-c and anti-Le ${ }^{\text {a }}$. The frequency of antibodies was shown in Table 2.

\begin{tabular}{|c|c|c|}
\hline $\begin{array}{c}\text { Antibody } \\
\text { Specificity }\end{array}$ & $\begin{array}{c}\text { Rh-D negative } \\
\text { women }(\mathbf{n = 1 0})\end{array}$ & $\begin{array}{c}\text { Rh-D positive } \\
\text { women }(\mathbf{n = 3})\end{array}$ \\
\hline Anti-D & $7(70)$ & - \\
\hline Anti-c & $1(10)$ & $1(33.33)$ \\
\hline Anti-E & - & $1(33.33)$ \\
\hline Anti-D+Anti-C & $1(10)$ & - \\
\hline Anti-Le & $1(10)$ & $1(33.34)$ \\
\hline
\end{tabular}

Table 2: Distribution of antibodies among allosensitized Rh-D negative and Rh-D Positive women.

Both primigravida and multigravida were included in the study population. The incidence of antibody formation in primigravida was $0.59 \%$ but in multigravida (G2, G3,G4) the frequency was $5.78 \%, 6.78 \%, 8.33 \%$ respectively (Table 3 ). Out of 13 women positive for the red cell allo-antibodies, $84.72 \%$ were in Rhesus blood group system and rest $15.38 \%$ were in Lewis blood group system. Among the antibodies of Rhesus blood group, the occurrence of anti-D (63.64\%) was the highest. The other rhesus antibodies detected were anti-c (18.18\%) and anti-E (9.09\%). The percentage of occurrence of combined antibody (anti-D+ anti-C) was 9.09\%. The incidence of non-anti-D in our study population was $1.65 \%$ (6/362).

\begin{tabular}{|c|c|c|c|}
\hline $\begin{array}{c}\text { Gravida } \\
\text { status }\end{array}$ & $\begin{array}{c}\text { Number of } \\
\text { Antibody }\end{array}$ & $\begin{array}{c}\text { Frequency } \\
(\%)\end{array}$ & $\begin{array}{c}\text { Antibody } \\
\text { Specificity }\end{array}$ \\
\hline $\begin{array}{c}G 1 \\
(n=168)\end{array}$ & 1 & $0.59 \%$ & Anti-Le ${ }^{a}$ \\
\hline \multirow[t]{4}{*}{$\begin{array}{c}G 2 \\
(n=121)\end{array}$} & 7 & $5.78 \%$ & Anti - D(4) \\
\hline & & & Anti-c(1) \\
\hline & & & Anti-Le $^{\mathrm{a}}(1)$ \\
\hline & & & $\begin{array}{c}\text { Anti-D+Anti- } \\
C(1)\end{array}$ \\
\hline \multirow[t]{2}{*}{$\begin{array}{c}G 3 \\
(\mathbf{n}=\mathbf{5 9})\end{array}$} & 4 & $6.78 \%$ & Anti-D (3) \\
\hline & & & Anti-E (1) \\
\hline $\begin{array}{c}G 4 \\
(n=12)\end{array}$ & 1 & $8.33 \%$ & Anti-c \\
\hline G5 $(\mathbf{n = 1})$ & 0 & 0 & - \\
\hline G6 (n=0) & 0 & 0 & - \\
\hline G7 $(\mathbf{n}=\mathbf{1})$ & 0 & 0 & - \\
\hline
\end{tabular}

Table 3: Antibody formation in relation to gravida status.

The titer of antibodies was important for fetal outcome. The critical titer of the anti-D was 16 . In our study we found two cases where anti-D titer was 32 which were above the critical level.

\section{Discussion}

In our study, the overall alloimmunization rate in pregnant women was $3.6 \%$. This appears high when compared with values from developed countries like Netherland studied by Koelewijn, et al. [8] (1.2\%) and De Vrijer, et al. [9] (2.7\%) and Sweden (0.5\%) studied by Filbey $D$, et al. [10] and lower when compared with values from developing countries where higher frequency values of $4.8 \%$ in Nigeria studied by Jeremiah, et al. [11] and of $10.2 \%$ in Mexico. This overall alloimmunization rate was also higher in comparison to other parts of India studied by Pahuja, et al. [12] (1.3\%) at New Delhi, Varghese, et al. [13] (1.5\%) at Vellore, South India.

Anti-D accounted for $53.85 \%$ of all alloantibodies in our study. Our results are in concordance with the results of several other studies. Gottvall, et al. found that anti-D was the cause of alloimmunization in $60 \%$ of cases. Lenkiewicz, et al. [14] and Howard, et al. [15] found that anti-D was responsible for $45.5 \%$ and $41 \%$ respectively, of cases of significant alloimmunization. In India Varghese, et al. [13] reported $34.2 \%$ anti-D alloimmunization in Southern part where as 


\section{Haematology International Journal}

Pahuja, et al. [12] reported $78.4 \%$ in Northern part. This can be attributed to the lack of implementation of standardised and universal anti-D immunoprophylaxis in India.

The most frequent and potentially significant antibody in our study was anti-D (1.93\%) followed by anti-c $(0.55 \%)$, anti-E $(0.28 \%)$ and anti-D+ anti-C $(0.28 \%)$. Although the occurrence of anti-Le $\mathrm{e}^{\mathrm{a}}$ in our study was $0.55 \%$ but it was not clinically significant and also not known to cause HDFN as these antigens are poorly developed at birth. In compared to other studies in India, anti-Le ${ }^{\mathrm{a}}$ was observed $4.5 \%$ by Suresh, et al. [16] and $10 \%$ by Varghese, et al. [13].

The present study included $63.43 \%$ of Rh-D negative women. Group-0 (48.52\%) was the highest among the D-negative women. The alloimmunization rate of $\mathrm{Rh}-\mathrm{D}$ negative group was $4.42 \%$ in our study. In the literature, there was a wide variation in alloimmunization rate among Rh-D negative women. Lurie, et al. [17] found a low alloimmunization rate of only $0.9 \%$ in Israel whereas AlIbrahim, et al. [18] found a higher rate of alloimmunization $7.1 \%$ in Saudi Arabia. Salola, et al. [19] recorded an alloimmunization rate of $2.98 \%$ in Rh-D negative women. The rate of $\mathrm{D}$-negative alloimmunization in our region was much more less $(4.42 \%$ vs $10.4 \%)$ in comparison to Northern part of India studied by Pahuja, et al. [12]. The rate of alloimmunization in Rh-D negative women in our study was much higher than that in Western countries.

Among allo-sensitized D-negative women, anti-D (63.64\%) was the most common antibody in our study. This was comparable with the study of Varghese, et al. [13] who reported anti-D alloimmunization of 58.73\%. We found anti-D combined with anti-C antibodies among D-negative women was $9.09 \%$ which is similar to Varghese, et al. [13].

The alloimmunization rate within Rh-D positive group in our study was $2.20 \%$. This was much higher than the findings of several other studies, such as those by Lurie, et al. [17] and Adenijii, et al. [20], who reported alloimmunization rate among Rh-D positive women of $0.2 \%$ and $0.15 \%$ respectively. In India, Sidhu, et al. [21] had reported $0.45 \%$ of alloimmunization among D-positive mothers. Our study was comparable to Al-Dughaishi, et al. [22] study who reported the prevalence of minor RBC antibodies alloimmunization among Rh- D positive pregnant women was $2.8 \%$. The high rate of alloimmunization among D-positive group in our study may be due to small sample size, all information obtained from one hospital which is a tertiary hospital which receives high risk populations and majority of the population was of low socio economic status where abortion rate was high.

$$
\text { Anti-c (33.33\%), anti-E(33.33\%) and Anti-Le }{ }^{\text {a }} \text { (33.34\%) }
$$

antibodies were encountered among D-positive women in our study with a equal percentage. Al-Dughaishi, et al. [22] reported anti-E (38\%) was the most common antibody among D-positive mothers. Sankaralingam, et al. [23] studied $1000 \mathrm{Rh}-\mathrm{D}$ positive women and found that the most common antibody was anti-E(85.7\%).

In our study we included $46.41 \%$ of primigravida and $53.59 \%$ of multigravida pregnant women whose gravida ranged from G2 to G7. Among primigravia the incidence of alloimmuniation was $0.59 \%$. Among multigravida the incidence was $5.78 \%, 6.78 \%, 8.33 \%$ in case of G2, G3, and G4 respectively. The present study was comparable with the Suresh, et al. [16] who studied on multigravia patients and found that the incidence in G2,G3 and G4 were $0.8 \%, 1.3 \%$, $10.5 \%$ respectively. The antibody formation increased with increasing gravida status. The gravida status was statistically significant ( $p$-value $=0.006$, Yate's correction method) and showed positive correlation with antibody formation in our study. The present study was comparable with Pahuja, et al. [12] study who found statistically significant which was p-value $<0.001$.

The present study showed $84.72 \%(11 / 13)$ of antibodies were confined within the Rhesus blood group system and rest(15.38\%) were in Lewis (anti-Le) blood group system. Among Rhesus antibodies the only anti-D was found in $63.64 \%$ where as anti-D combined with anti-C was found in 9.09\% pregnant women. Al-Dughaishi, et al. [22] studied on Rheshus alloimmunization in pregnant women and found that the most common rhesus antibody was anti-D(66.7\%) which is comparable to our study. Bondagji, [24] had also reported anti-D was the most common alloimmunization among Rhesus antibodies.

The widespread use of protective anti-D immunoglobulin programme against Rh-D alloimmunization has an impact of reducing alloimmunization due to anti-D and can unmask the risk of other RBC antibodies alloimmunization, which are the significant causes of hydrops fetalis and haemolytic diseases of fetus and newborn. Among the non Rh-D antibodies, anti-c and anti-K are those most likely to cause haemolytic disease of newborn [25]. The incidence of non-anti-D antibodies in the present study was $1.65 \%$. This is comparable to the reports of $1.62 \%$ by Smith, et al. [26] and $1.6 \%$ of Karim, et al. [27] in Pakistan. Gunduz et al. [28] from Turkry, Al-Dughasi [22] from Oman and Jeremiah, et al. [11] from Nigeria found that the non-anti-D incidence to be $1.21 \%, 2.8 \%$ and $3.4 \%$ respectively. A Croatian study Dijak S, et al. [29] reported that the clinically significant non-D antibodies producing HDFN was approximately $55 \%$.

Among non-anti-D antibodies, anti-c (15.38\%) was the most frequent and potential antibody detected in our study 


\section{Haematology International Journal}

which contradict Al-Dughasi [22] study who reported the most common antibody was anti-E (38\%). In our study the anti-E was only $7.69 \%$. The other non-anti-D in our study was anti-Le ${ }^{\mathrm{a}}(15.38 \%)$ and anti-C $(7.69 \%)$ which combined with anti-D. Karim, et al. [27] from Pakistan studied on nonanti-D antibodies and found that anti-C, anti-E, anti-Le ${ }^{\mathrm{a}}$ were $5 \%, 5 \%$ and $15 \%$ respectively. Our study was comparable to Karim, et al. [27] study.

Antibody titration is a semi quantitative method of determining antibody concentration. In pregnancy, antibody titration is performed to ascertain whether women are having significant levels of antibodies which may lead to HDFN. The critical titer for anti-D is 16 in the AHG phase [30] and 8 is generally accepted for kell system antibodies [31]. In our study we found two cases where the antibody titer of anti-D was equal to or more than 16. In most of our patients the antibody titer was below 16 . The titer of the pregnancy was observed at the time of antibody identification irrespective of gestation. Al-Dughashi, et al. [22] was found two anti-Kell with titer 1:128 and 1:1024. When the titre was above critical level, the patient should be followed up and the titre should be monitored at every four weeks interval till delivery. In our study we lost follow up of two patients. The follow up study include patient counselling, clinical problems, clinical protocol for screening and prevention of $\mathrm{Rh}$ immunization.

In most US centres, once a maternal anti-D is between 1:8 and 1:32, serial Amniocentesis or serial fetal middle cerebral artery (MCA) Doppler measurement are obtained. In Europe and United Kingdom, the quantity of circulating anti-D is calibrated to an International standard and reported in $\mathrm{IU} / \mathrm{ml}$. Once the anti-D level of $15 \mathrm{IU} / \mathrm{ml}$ or greater is reached invasive testing is recommended. Amniotic fluid $\Delta O D 450 \mathrm{~nm}$ measurement can be used to monitor billirubin and progression of fetal anemia. If the Doppler MCA velocity measurement are $>1.5 \mathrm{MoM}$ or Amniotic fluid $\Delta$ OD450 $\mathrm{nm}$ value in upper zone 2 or zone 3 of Liley curve or intra uterine zone of Queenan curve, fetal sampling is warranted for measurement of fetal hematocrit. If fetal hematocrit below $30 \%$ and the gestational age was below 35 weeks then management protocol should be intrauterine transfusion. Fetal hematocrit less than $30 \%$ with gestational age at or above 35 weeks require immediate delivery.

\section{Limitation of our Study}

a) Antibody identification panel used in our study was not framed to identify anti-Mi, which was reported to be most frequent irregular antibody in Asians.

b) Paternity test should be under taken to see if the patient's partner is heterozygous for the offending antigen which was not done in our study.

c) Anti-K tends to react poorly in low ionic strength solution and may be relatively difficult to detect with the
LISS-IAT.

d) Antibody subclass was not identified in our study which is most important for severity of fetal anaemia.

e) Fetal Genotype for accurate determination of fetal D antigen was not done in our study.

\section{Conclusion}

It is important to know that not all antibodies identified during pregnancy will cause HDFN. Only clinically significant antibodies will cause mild to severe HDFN. Many developed nations have implemented regular screening of all pregnant women and even have national screening programs. In our study, anti-D(1.93\%) was the most common antibody detected. The occurrence of anti-D alloimmunization is still seen now a day's despite the routine practice of giving prophylactic anti-D immunoglobulin antenatally and postnatally to all Rh-D negative women. Non Rh-D red cell antibodies associated with HDFN will continue to challenge practitioners because the development of these antibodies is often related to transfusion therapy of mother and child. In addition, prophylactic immune globulins are unlikely to be developed due to rarity of these situations. The frequency of non-anti-D antibodies in our study was $1.65 \%$ among which anti-c was the most common antibody. The present study concluded that the alloimmunization among Rh-D positive women was $2.20 \%$. This suggests that the irregular antibodies during pregnancy were detected not only in Rh-D negative mother but also in Rh-D positive women as well. The titer of the antibody should be closely monitored and if it crosses the critical level, than the clinical course should be followed up and manage the patient accordingly. Hence, keeping in view all of the above, universal antenatal screening in all pregnant women needs to be initiated, since in Rh-D positive women just like Rh-D negative women alloantibodies can be formed. A close follow up throughout pregnancy is required to detect irregular antibodies .Although universal screening seems justified; the cost and infrastructure requirement would be immense. Developing countries and under resourced nations need to consider universal antenatal screening and frame guidelines accordingly.

\section{References}

1. Race RR, Sanger R (1968) Blood groups in man. $5^{\text {th }}$ (Edn.), Oxford: Blackwell.

2. Springer GF, Horton RE, Forbes M (1959) Origin of antihuman blood group B agglutinins in white Leg horn chicks. J Exp Med 110(2): 221-244.

3. LandsteinerK(1900)Zurkenntnis der antifermentativen, Lytischen und agglutinierenden Wirkungen des Blutserunes under der lymphe. Zbl Bart 27: 357-362. 


\section{Haematology International Journal}

4. http://www.isbtweb.org/nc/working parties red cell immunogenetics and blood group terminology.

5. Choavartana R, Uer Areewong S, Makanataksol S (1997) Fetomaternal transfusion in normal pregnancy and during delivery. J Med Assoc Thai 80(2): 96-100.

6. Weinstein L (1982) Irregular antibodies causing hemolytic disease of the newborn: A continuing problem. Clin Obstet Gynecol 25(2): 321-332.

7. Smith BD, Harber JM, Queenan JT (1967) Irregular antibodies in pregnant women. 29: 118-124.

8. Koelewijn JM, Vrijkotte TG, Van der Schoot CE, Bonsel GJ, M De Haas (2008) Effect of screening for red cell antibodies, other than anti-D, to detect hemolytic disease of the fetus and newborn: a population study in the Netherlands. Transfusion 48(5): 941-952.

9. De Vrijer B, Harthoorn-Lasthuizen EJ, Oosterbaan HP (1999) The incidence of irregular antibodies in pregnancy: a prospective study in the region of the s-Hertogenbosch. Ned Tijdschr Geneeskd 143(50): 2523-2527.

10. Filbey D, Hanson U, Wesstrom G (1995) The prevalence of red cell antibodies in pregnancy correlated to the outcome of the newborn: a 12 year study in Central Sweden. Acta Obstet Gynecol Scand 74(9): 687-692.

11. Jeremiah ZA, Mordi A, Buseri FI, Adias TC (2011) Frequencies of maternal red cell alloantibodies in Port Harcoat, Nigeria. Asian Journal of Transfusion Science 5(1): 39-41.

12. Pahuja S, Gupta SK, Pujani M, Jain M (2011) The prevalence of irregular erythrocyte antibodies among antenatal women in Delhi. Blood Transfus 9(4): 388-393.

13. Varghese J, Chacko MP, Rajaiah M, Daniel D (2013) Red cell alloimmunization among antenatal women attending a tertiary care hospital in South India. Indian J Med Res 138(1): 68-71.

14. Lenkiewicz B, Zupanska B (2003) Significance of alloantibodies other than anti-D hemolytic disease of the fetus and newborn (HDF/N). Ginekol Pol 74(1): 48-54.

15. Howard H, Martlew V, McFadyen L, et al. (1998) Consequences for fetus and neonate of maternal red cell alloimmunisation. Arch Dis Child Fetal Neonatal Ed 78(1): 62-66.

16. Suresh B, Sreedhar Babu KV, Arun R, Jothibai DS, Bharati $T$ (2015) Prevalence of "Unexpected antibodies" in the antenatal women attending the Government Maternity
Hospital, Tirupati. J Clin Sci Res 4: 22-30.

17. Lurie S, Eliezer E, Piper I, Woliovitch I (2003) Is antibody screening in $\mathrm{Rh}(\mathrm{D})$-positive pregnant women necessary? J Mater Fetal Neo-natal Med 13: 227-231.

18. Al-Ibrahim NA, Al Saeed AH (2008) Red blood cell alloimmunisation among Saudi pregnant women in the central province of Saudi Arabia. Kuwait Med J 40: 116123.

19. Salola A, Sibai B, Mason JM (1983) Irregular antibodies: an assessment of routine prenatal screening. Obstet Gynaecol 61(1): 25-30.

20. Adeniji AA, Fullar I, Dale T, Lindow SW (2007) Should we continue screening Rhesus D positive women for the development of atypical antibodies in late pregnancy? J Matern Fetal Neonatal Med 20(1): 59-61.

21. Sidhu M, Bala R, Akhtar N, Sawhney V (2016) Prevalence, Specificity and Titration of Red cell Alloantibodies in Multiparous Antenatal Female at a Tertiary care center from North India. Indian J Hamatol Blood Transfus 32(3): 307-311.

22. Al Dughashi T, Al Harrasi Y, Al Duhil M, Al Rubkhi I, Al Riyami N, et al. (2016) Red cell Alloimmunization to Rhesus Antigen Among Pregnant Women Attending a Tertiary Care Hospital in Oman. Oman Med J 31(1): 4547.

23. Sankaralingam P, Jain A, Bagga R, Kumar P, Marwaha $N$ (2016) Red cell alloimmunization in Rh D positive women and neonatal outcome. Transfus Apher Sci 55(1): 153-158.

24. Bondagji NS (2011) Rhesus alloimmunization in pregnancy: A tertiary care center experience in the Western region of Saudi Arabia. Saudi Med J 32: 10391045 .

25. Chandrasekhar A, Morris KG, Tuban TRJ, Tharma S, Mc Clelland WM (2001) The clinical outcome of non-RhD antibody affected pregnancies in Northern Ireland. Ulst Med J 70(2): 89-94.

26. Smith BD, Haber JM, Queenan JT (1967) Irregular antibodies in pregnant women. Obstet Gynecol 29(1): 118-124.

27. Karim F, Moiz B, Kamran N (2015) Risk of maternal alloimmunization in South Pakistan-a study in a cohort of 1000 pregnant women. Transfus Apher Sci 52(1): 99102.

28. Gunduz E, Akay OM, Teke HU, Gülbaş Z (2010) Incidence 


\section{Haematology International Journal}

of red-cell alloimmunization due to non-anti-D antibodies during pregnancy: An experience from Turkey. Transfusion and Apheresis Science 43(3): 261263.

29. Dijak S, Stefanovic V, Capkun V (2011) Severe hemolytic disease of fetus and newborn caused by red blood cell antibodies untected at first trimester screening. Transfusion 51(7): 13780-13788.
30. Fung MK, Grossman BJ, Hillyer CD, Westhoff CM (2014) Perinatal Issue in Transfusion Practice, AABB Technical Mannual 18 ${ }^{\text {th }}$ (Edn.), 22: 563.

31. Vaughan JI, Manning M, Warwick RM, Letsky EA, Murray NA, et al. (1998) Inhibition of erythroid progenitor cells by anti-kell antibodies in fetal alloimmune anaemia. $\mathrm{N}$ Engl J Med 338(12): 798-803. 